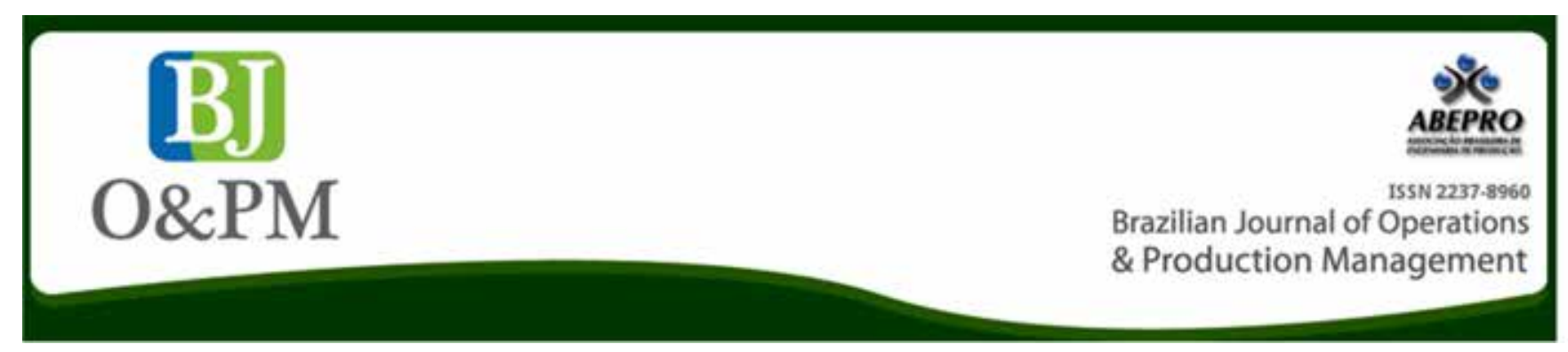

\title{
DISTANCE LEARNING FOR TRAINING BUSINESS GAME TUTORS
}

\author{
Mariana de Toledo Marinho ${ }^{1}$, José de Souza Rodrigues ${ }^{1}$, Kátia Livia Zambon ${ }^{1}$
}

\section{São Paulo State University}

\begin{abstract}
This work is the result of research that proposes the incorporation of Distance Learning into a Business Game as a strategy to enhance tutor training, considering entrepreneurship difficulties faced by public school teachers. Part of the problem could be attributed to subject type, because, in general, it is not common to find entrepreneurship on school curricula. The Distance Learning (DL) activities were developed using the Moodle platform and were structured by topic to increase educational flexibility and achieve a better balance between individual reflection and online discussion. It was developed in four steps: course content development; course evaluation by computer technicians; course restructuring based on course evaluation by computer technicians; and course evaluation by teachers from the public school system. A preliminary test was performed with informatics technicians to technically evaluate the learning environment. Based on this, the course was restructured, applying corrections and adjustments in order to improve environment usability. After corrections, a final test was conducted with public school system teachers to analyze user perception, which gave a positive result. Virtual learning environment evaluation is complex and multidisciplinary, requiring the technical knowledge of internet programming and a conceptual knowledge of education, especially in the field of learning. When the evaluation done by teachers was examined it was found that deficiencies pointed out by computer technicians had been resolved, giving a positive rating. This current research concludes that DL can improve the use of games, because it is possible to structure content related to the learning gaps of specific groups of students. In this respect, the use of games results can guide the development of content.
\end{abstract}

Keywords: Entrepreneurship; Business Game; Distance Learning Course. 
Brazilian Journal of Operations \& Production Management

Volume 14, Número 1, 2017, pp. 187-195

DOI: 10.14488/BJOPM.2017.v14.n2.a6

\section{INTRODUCTION}

This paper is the result of previous research (Rodrigues et al., 2012) using the game Bom Burguer with public school teachers. It had been noticed that teachers had difficulties in terms of using the game because of their unfamiliarity with the subject of entrepreneurship.

Considering that Brazilian legislation does not consider the teaching of entrepreneurship in state primary and secondary schools compulsory (see MEC, 2015 and CNE/ $C P, 2002)$, the teaching of entrepreneurship depends on the individual actions of teachers and schools or on institutions and individuals in society. Research that facilitates the teaching of entrepreneurship or improves existent conditions is, therefore, very important. In this study, the main objective was to facilitate the process of capacitating tutors to use the game Bom Burguer through Distance Learning, as a strategy to enable the teaching of entrepreneurship in state schools in Bauru and surrounding region.

In this specific case, researchers considered that Distance Learning could be an effective way to overcome the barriers and difficulties found in the previous research (Rodrigues et al., 2012). One such barrier is the state school teachers' limited domain in terms of content associated with entrepreneurship. Thus, an environment was developed to deliver content related to entrepreneurship and the Bom Burguergame, whose functionalities and objectives were used as extra material, since the game has a manual, was used. The general premise of the research was that, after the training, tutors would be able to use the same environment to teach entrepreneurship to their students. For this reason, the participation of technicians in the research was considered very important, because they share similarities with typical state school students who are, for example, under 18 and are in high school as well. As a result, the research helped to improve the environment previously developed, and simplified the process of training and preparing teachers to use the Bom Burguer game (chosen because of its associated content within the environment of entrepreneurship and the fact that it requires little support to use) in Brazilian state schools. The game was developed to facilitate the teaching-learning process, involving various entrepreneurship subjects, such as decision-making, inventory management, pricing, competition, accounting and financial reports, among others.

The research can be classified as qualitative, because its objectives are related to improving the qualification process of tutors using $\mathrm{DL}$, and for this reason opinion questionnaire research with technicians and teachers was used, aiming to evaluate the changes made to the Distance Learning environment to correct some shortcomings detected when it was first developed. Although the sample size was small, the results indicated that $D L$ can improve the process of enabling tutors to use the game. This paper comprises an introduction, research background, method, data analysis and conclusion.

\section{RESEARCH BACKGROUND}

Entrepreneurship is not part of the undergraduate curriculum for teachers in Brazil. The word entrepreneurship does not appear in the resolution 2, July $1^{\text {st }}, 2015$, which establishes the Brazilian National Curriculum Guidelines for undergraduate courses, teacher training courses for graduates and second-degree courses and continuing education (MEC, 2015). The same is true for the previous document of February $18^{\text {th }}, 2002$, which establishes the National Guidelines for the formation of Teachers of Basic Education, at higher level graduate degree courses (CNE/CP, 2002).

Europe started an education reform in 2012 with a program named "Rethinking Education", with specific actions related to entrepreneurship: "(...) only six Member States have a specific strategy for entrepreneurship education" (European Commission, 2012, p.4). In 2014 the European Union published the document "Entrepreneurship Education: A Guide for Educators" in which the main points of its education reform, focusing on the education of teachers of basic education, is presented. For the European Commission (2012, p. 3), "Transversal skills such as the ability to think critically, take initiatives, solve problems and work collaboratively will prepare individuals for today's varied and unpredictable career paths... particularly entrepreneurial skills". According to Kurako (2005), the USA government establishes the general guidelines to education, and the assessment of education uses accreditation which is made by entities “(...) comprised of institutions and academic specialists in specific subjects, who establish and enforce standards of membership and procedures for conducting the accreditation process" (U.S. Department of Education, 2017). This characteristic of the USA education system helps schools and communities make improvements locally; however, the national system of schools assessment can conflict with radical innovations because a considerable part of this assessment is focused on math and reading tests, conflicting with the demands of a genuine entrepreneurship education (McShane, 2016). This author believes that in the next two decades:

educational entrepreneurship will encounter a funding community, a policy environment, and a changing educational landscape that will profoundly affect the types of ventures they are able to create and the ability of those ventures to scale, grow, and meet children's needs (McShane, 2016, p.3). 
Considering the necessity of making changes that align the education process with the new demands on education, the use of Distance Learning (DL) to complement the learning supported by business games was considered. DL has been a method of delivery for instructional courses for many years, dating back to the $19^{\text {th }}$ century. Students who could not attend regular classes received content by mail. This was the beginning of DL (Benjacob, 1998), that had occurred by the 1950s (Conde, Muñoz, García, 2008). The development of technology brought new possibilities, and the systems that support DL have been used in a variety of ways, from a pure learning system to a mechanism of support for classroom lessons. It can be used to deliver content, assess students, and facilitate the interactions between students, teachers or both. There are a lot of studies related to DL (Keegan; 1996, Wolfe; Flores; Ritchie; 2002, Batista \& Cornachione Jr.; 2005, Smith; 2010, Bagdonas et al., 2010, Moran et. al., 2013, Hafeez; Gujjar; Noreen; 2014, Sezer; 2016, Griffiths; 2016, Goodrich; 2016).

Smith (2010) described DL as any instructional arrangement in which teachers and students are geographically separated to an extent requiring communication through media. To Sezer (2016) DL is a concept in which teachers, students and course content are not in the same location or, in his words, at least one of the three is located in a different place. According to Smith (2010, p. 195) “One important factor that makes DL so unique is that it allows learning to be an individual matter". Today, DL Courses are strongly supported by technology, have intensive use of Information and Communication Technologies (ICT), interaction facilitation between physically distant teachers and students, audiovisual resources employment to develop content and activities, and greater adaptability to user in distribution and content use, among other advantages. Griffiths (2016, p. 2) presents a definition of $D L$ “(...) as a planned teaching-learning process that uses one or more technologies as a conduit for learning when students are separated from the instructor(...)" and she continues "(...) Interactions may be in real-time (synchronous) or delayed (asynchronous) (...)".

Goodrich (2016) analyzed the improvement of distance education for disabled students, Sezer (2016) analyzed the attitudes and opinions of students regarding DL, Bagdonas et al. (2010) analyzed the use of simulating and gaming to enhance entrepreneurship, Wolfe; Flores; Ritchie (2002) compared learning outcomes and supposed internet-associated benefits of using a game in Distance Education, Batista et Cornachione Jr. (2005) analyzed the effect of learning styles on satisfaction and perceived learning on online games, and Hafeez, Gujjar, Noreen (2014) studied the demand for technology by users of DL in Turkey. Although technology is part of the definition of Distance Education given by Griffiths (2016), it has brought more than the possibilities of creating learning environments; it furnishes devices and infrastruc- ture which can dramatically change the teaching-learning process. The smart board, for example, connects the classroom environment to cyber space and offers a lot of resources that work as DL systems, such as recording and sharing the content developed during a class. Thus, a unique device offers a variety of class and pedagogical configuration method possibilities.

Keegan (1996) identified six key elements of DL: 1) Separation of teacher and learner; 2 ) Influence of an educational organization; 3) Use of media to link both teacher and learner; 4) Two-way exchange of communication; 5) Learners as individuals rather than grouped and; 6) Education as an industrialized form. For Moran et. al (2013), DL is strategic to make profound changes in education as a whole, becoming an increasingly important option for learning throughout life, continuing education, vocational acceleration and enabling a reconciliation of study and work.

There are a great number of platforms to DL. In this research the Moodle Platform, provided by UNESP (São Paulo State University), was used. The Moodle Platform permits the creation of online courses, subject pages, working groups and learning communities (Alves et al., 2009). Aiming to facilitate the use of DL institutionally, the university where this research was carried out, UNESP, created a DL Center, which is responsible for providing the Moodle environment and giving support to its academic staff. Content developed in Moodle addresses topics such as entrepreneurship, Business Games and Bom Burguer (the game used in this research) to achieve the goal of training tutors.

Initially, Business Games and entrepreneurship association occurred in executive training (Burch Jr., 1969). Many competences and abilities associated with entrepreneurship are demanded from professionals nowadays, requiring that they develop them throughout the education process. Pinto et al. (2016) indicated know how to act, know how to mobilize, know how to transfer, know how to learn, know how to engage yourself, to have strategic vision and to take responsibility as the eight main competences of a social entrepreneur. Robles et Zárraga-Rodríguez (2015) found twenty competences, including some of the social ones. Experts were invited to list these competences according to their relevance and importance. The eight best assessed were Risk assumption; Initiative; Leadership; Teamwork, Responsibility, Autonomy/self-determination, Self-confidence and Integrity.

For Goldschmidt (1977, p. 43), one the first researchers of the use of games for educational purposes in Brazil, "the business games allow to continuously simulate various types of decisions and alternatives, so that participants are able to evaluate the results of different decisions". 
For these characteristics, learning mediated by business games has great potential synthesis and interconnection content for being a multidisciplinary didactic and pedagogical resource. In addition, business games have the advantage of allowing students to experience the decision-making process without the risk of prejudicing real organizations (Santos et Lovato, 2007). It is a tool that facilitates the theoretical knowledge improvement of subjects related to business management, and encourages entrepreneurship and the systemic view of organizations, requiring students to adopt a proactive attitude to the education process. Santos et Lovato (2007) built a framework where they present the strengths and weaknesses of games as a support to teaching during the learning process. According to them the main advantages are to: make learning easier, contribute to the understanding of abstract subjects, permit multiple representations of reality, instill an interdisciplinary approach, offer great satisfaction for participants, and stimulate the active participation of students. As weaknesses, they suggest high cost, lack of institutional infrastructure to support the use of games, and the adequacy of game interface software.

As the Bom Burguer game is available on a web platform, the proposition of using DL to increase its educational capacity began in a natural way. The game involves selling a sandwich and a soda combination (a kit). Students are organized into rooms, in which they compete against each other. The rooms are parameterized by the teacher. Each enterprise can participate in several rooms, but its result is specific to each room. In other words, the result is not global, but local. Therefore, students can test distinct strategies by playing in different rooms. In the student environment, company management involves the purchase of materials, pricing, marketing investment, inventory control and company resources. These decisions are made based on the sales of kits, which generate material requirements.

On the decision page, after students forecast the quantities of kits, fields with quantities of materials necessary to make them, such as soda, bread, lettuce, cheese, tomato, hamburger must be filled and decisions must be made regarding how much to invest on advertising and which media channel to invest in. The data is processed and the results generated are presented in reports and charts that can be used to build scenarios to support decision making in the next round. Each round generates new reports and charts, and a ranking representing company competitiveness in the "market" (room) proposed in the game. For this reason, to work as tutors, public school teachers need to know math, information technology basics and concepts of entrepreneurship. In previous research with a group of public school teachers barriers to these skills were found. As tutors, the teachers perform all the activities related to the use of a game, such as creating classes (group of students who play the game), running the game, changing the game parame- ters, checking who is playing or not, assessing the students and analyzing and debating the results with them.

In this research, the main objective was to analyze whether a recognized DL course could be used to overcome barriers diagnosed in Public School teacher training courses. These courses were developed to enable teachers of public schools to use the Bom Burguer game, as a way of supporting the entrepreneurship education in public schools from the region of Bauru.

To meet the general objective, the following specific objectives were defined:

a) Create teaching materials, using quiz, crossword, chat, forum, briefing, video, and reporting with COLLES (Constructivist On-Line Learning Environment Survey) and ATTLS (Attitudes to Thinking and Learning Survey), which were structured as a questionnaire in the Moodle environment, according to Cole and Foster (2008);

b) Improve the environment with resources taken from the users' feedback, using the assessment framework proposed by Juwah et al. (2004);

c) Ensure that the activities include how to use game, entrepreneurship and identity learning content, as proposed by Kolb et Kolb (2009).

\section{METHODS}

This research is applied, because it intends to solve a problem (Gil, 2010): to overcome the barriers of using a business game when developing a DL course. Considering the methodological approach of assessment of the environment developed, it is qualitative.

Two questionnaires were used to collect data, one multiple choice type and one using the Likert scale. Both were developed by the authors to determine student profile and analyze course structure, respectively. Considering the opinions of technicians, who were interviewed about the environment of the DL course, regarding the previous version of the course, improvements were made. After correcting the weaknesses pointed out by technicians, the new environment was used to train a group of teachers, a questionnaire being used to collect data about their opinion in terms of the environment. For Gil (2010), survey questionnaires request information from a large group of people, regarding problems studied through quantitative analysis, to obtain conclusions corresponding to the data collected. Furthermore, course environment activities also allow data to be collected in two possible ways. Firstly, using the database of the game. 
Secondly, using data collected by Moodle, such as activities made by teachers, their answers, and how many times they access activities or pages etc. This research presents only the data collected by the two questionnaires because they are focused on the problem proposed in this study, using DL to facilitate the use of the game by tutors.

The data was analyzed, aiming to answer questions such as: whether courses for tutors promoted the support needed to use this tool to assist the learning process, whether available resources helped in preparing lessons, whether teachers used resources learned in their classes, and whether learning was facilitated by the course in the distance education environment.

During the test phase, part of the experiment was conducted using the observation technique, as defined by Marconi et Al. (2007), and analyzed whether there were difficulties in terms of environment use.

A survey was conducted with two groups of volunteers: computer technicians and public school teachers. The technicians were students of the Technical College of Bauru, where everyone knew Bom Burguer and most had already done at least one distance education course. They were an important element because they helped to test the system, and evaluated the course from the perspective of students. The teachers were from a public school, most of whom had not done a DL course, and none of them knew of the Business Game. These teachers belong to a special group of the education system of the São Paulo State, called Family School. They are responsible for developing activities during the weekends with students and members of the community that surround the school where they are allocated. The group was composed of five teachers from different disciplines such as Portuguese, Math, Physics and Physical Education, from a total of 45 teachers allocated in some of the 50 State schools supervised by the School Board of Bauru (SESP, 2015). The questionnaire data collected was analyzed using basic descriptive statistics, transformed into percentages. This data, collected by observation and the opinion of technicians and teachers, was analyzed qualitatively.

\section{RESULTS}

The Moodle platform was used to develop the course. It is an open source software to create solutions such as online courses, subject pages, working groups and learning communities. Academic Moodle was provided by the NEaD (Distance Teaching Center) from UNESP. The course was designed using topics to increase educational flexibility and achieve better balance between individual reflection and online discussion (Alves; Barros; Okada, 2009). In order to evaluate it technically and conceptually, it was developed in four stages:
1. Content development;

2. Technical evaluation;

\section{Course restructuring;}

\section{Content evaluation by teachers.}

This section presents the results obtained in these four stages of course development.

\section{Content development}

The course content was developed and split into three main themes: learning identity, entrepreneurship and Bom Burguer.

The content related to learning identity was extracted from Kolb et Kolb (2009) and aimed to make the student and/or tutor reflect on how they deal with the challenges they face in their lives, that is, dealing with learning itself. For Kolb et Kolb (2009), the way people make choices when faced with challenges determines their learning identity, classified as "fixed learning identity" or "learning identity". This text was chosen because entrepreneurship is related to behavioral aspects and change. In this sense, the content helps students to think about their behavior and how they deal with their limitations and difficulties.

Students need to do this kind of self-assessment, especially because business games are considered a method of "experiential learning" (Santos et Lovato, 2007), which implies changes in terms of the thinking and behavior of students, teachers and institutions. This reflection was included in the environment as a way for students and/or tutor to think about how their posture affects the results achieved. The entrepreneurship theme aimed to generate learning interms of entrepreneurship, including a reflection on entrepreneurship under two foci: the work and creation world and business management. And, finally, how using Bom Burguer is taught, aiming to eliminate, as much as possible, the lack of entrepreneurship content, which can affect the use of the game and difficulties using the game, such as how to access its functionalities and environment interface difficulties.

\section{Technical evaluation}

Regarding the technical evaluation, computer technician students analyzed the technical aspects of the course, such as usability and course environment errors. These aspects were analyzed using the Likert scale questionnaire and interview. 
Brazilian Journal of Operations \& Production Management

Volume 14, Número 1, 2017, pp. 187-195

DOI: 10.14488/BJOPM.2017.v14.n2.a6
Data showed that they considered the course appropriate. However, they suggested some adjustments in terms of course usability and changes to some activities. As can be seen in Table 1, course questions have two negative evaluations, where $60 \%$ of technicians were indifferent regarding usability and $80 \%$ did not totally agree with the affirmation that there were no errors in the system. During the interview, they also "sometimes felt lost in course" and reported some consistency errors in activities.

Table 1. Evaluation of the course in Moodle, according to computer technicians

\begin{tabular}{|c|c|c|c|c|c|}
\hline Affirmative/Scale & SD & DIS & NAND & AG & SA \\
\hline $\begin{array}{c}\text { Moodle is a good tool to } \\
\text { support teaching learning. }\end{array}$ & 0 & 0 & $20 \%$ & $40 \%$ & $40 \%$ \\
\hline $\begin{array}{c}\text { I liked the course module } \\
\text { division. }\end{array}$ & 0 & 0 & 0 & $20 \%$ & $80 \%$ \\
\hline $\begin{array}{c}\text { The usability of the course } \\
\text { is good. }\end{array}$ & 0 & 0 & $60 \%$ & 0 & $40 \%$ \\
\hline $\begin{array}{c}\text { I didn't have problems with } \\
\text { respect to system errors. }\end{array}$ & 0 & $20 \%$ & $20 \%$ & $40 \%$ & $20 \%$ \\
\hline
\end{tabular}

$\mathrm{SD}=$ strongly disagree, $\mathrm{DIS}=$ Disagree, $\mathrm{NAND}=$ Neither agree nor disagree; $A G=$ Agree,$S A=$ Strongly agree

Regarding learning resources evaluation (seen in Table 2), PDF texts, Prezi presentations, Hot Potatoes activities and essay tasks were not well accepted. In interview, technicians argued that PDF texts were "long and tedious", Prezi presentations were "vague", Hot Potatoes activities were "vague, confusing and presented consistency errors" and essay tasks were "very extensive".

Table 2. Evaluation of the learning resources, according to computer technicians.

\begin{tabular}{|c|c|c|c|c|c|}
\hline Affirmative/Scale & SD & DIS & NAND & AG & SA \\
\hline YouTube videos & 0 & 0 & 0 & $20 \%$ & $80 \%$ \\
\hline PDF texts & $20 \%$ & 0 & $20 \%$ & $40 \%$ & $20 \%$ \\
\hline Prezi presentation & 0 & $20 \%$ & 0 & $20 \%$ & $60 \%$ \\
\hline Hot Potatoes & $40 \%$ & 0 & $20 \%$ & $20 \%$ & $20 \%$ \\
\hline BG Bom Burguer & 0 & 0 & 0 & $60 \%$ & $40 \%$ \\
\hline $\begin{array}{c}\text { Links directed to } \\
\text { other sites }\end{array}$ & 0 & 0 & $40 \%$ & $20 \%$ & $40 \%$ \\
\hline $\begin{array}{c}\text { Activities with Moo- } \\
\text { dle questionnaires }\end{array}$ & 0 & 0 & $40 \%$ & $40 \%$ & $20 \%$ \\
\hline Essay tasks in Moodle & 0 & $20 \%$ & $20 \%$ & $60 \%$ & 0 \\
\hline
\end{tabular}

$\mathrm{SD}=$ strongly disagree, $\mathrm{DIS}=$ Disagree, $\mathrm{NAND}=$ Neither agree nor disagree; $A G=$ Agree,$S A=$ Strongly agree

Table 2 demonstrates that it is necessary to carefully consider the resources used in DL. Hot Potatoes, for example, is an easy way to build a question bank, but the first version was not well assessed by technicians. Thus, to use DL, it is necessary to assess the content and other variables, such as the visual characteristics and the organization of information on the screen.

\section{Course restructuring}

To solve problems identified through technical evaluation, the course was restructured. Regarding the usability question, Moodle topics were linked using HTML files. According to Silva (2008), HTML allows links between files to be created, enabling virtual navigation.

Other problems cited were also corrected. Hot Potatoes activities and extensive essay tasks were changed to eliminate consistency errors. Prezi presentations were enriched and became the main text of the page. PDF texts, considered extensive, were replaced by a summary on the homepage with a link to download the full version, thus transforming them into background material. In this section, it is possible to identify other aspects associated with the environment used. DL permits the use of a lot of resources, but the use of long texts and videos should be avoided.

\section{Content evaluation}

Finally, to evaluate the content of the course a new experimental test with teachers was conducted. As can be seen in Table 3, questions regarding usability and system errors received positive evaluations. The same applies in learning resource questions, as can be seen in Table 4: Prezi presentation, Hot Potatoes activities and PDF texts received better ratings.

Table 3. Evaluation of the Moodle course, according to teachers

\begin{tabular}{|c|c|c|c|c|c|}
\hline Affirmative/Scale & SD & DIS & NAND & AG & SA \\
\hline $\begin{array}{c}\text { Moodle is a good tool } \\
\text { to support teaching } \\
\text { learning. }\end{array}$ & 0 & 0 & 0 & $20 \%$ & $80 \%$ \\
\hline $\begin{array}{c}\text { I liked the module divi- } \\
\text { sion of the course. }\end{array}$ & 0 & 0 & 0 & $60 \%$ & $40 \%$ \\
\hline $\begin{array}{c}\text { The course usability is } \\
\text { good. }\end{array}$ & 0 & 0 & 0 & $40 \%$ & $60 \%$ \\
\hline $\begin{array}{c}\text { I didn't have problems } \\
\text { with respect to system } \\
\text { errors. }\end{array}$ & 0 & 0 & $20 \%$ & $40 \%$ & $40 \%$ \\
\hline
\end{tabular}

$\mathrm{SD}=$ Strongly disagree, $\mathrm{DIS}=$ Disagree, $\mathrm{NAND}=$ Neither agree nor disagree; $\mathrm{AG}=$ Agree, $\mathrm{SA}=$ Strongly agree

Table 3 and 4 analyzed distinct aspects of the learning environment. In table 3, researchers focused on the structure of the course and the DL environment, while in Table 4, interest was on the resources used to build the $\mathrm{DL}$ environment. Both received a better assessment when compared with the previous version of the DL course. It is possible to conclude that the new environment is better than the first. In Table 3 , there is a specific question related to the main objective of this research, "Moodle 
is a good tool to support teaching learning". Although it is about Moodle, it refers to DL. Teachers (future tutors) would answer negatively if the environment in all aspects related to learning was not effective in providing learning. As a suggestion for future research, an experiment with a control group could be made, one group using the game without the support of the DL course, and the other, with. The two groups could then be compared in respect of content retention and the number of hits.

Table 4 - Evaluation of the learning resources, according to teachers

\begin{tabular}{|c|c|c|c|c|c|}
\hline Affirmative/Scale & SD & DIS & NAND & AG & SA \\
\hline YouTube videos & 0 & 0 & 0 & $60 \%$ & $40 \%$ \\
\hline PDF supporting texts & 0 & 0 & 0 & $40 \%$ & $60 \%$ \\
\hline Prezi presentations & 0 & 0 & $20 \%$ & $40 \%$ & $40 \%$ \\
\hline Hot Potatoes & 0 & 0 & $40 \%$ & $20 \%$ & $40 \%$ \\
\hline BG Bom Burguer & 0 & 0 & $20 \%$ & $20 \%$ & $60 \%$ \\
\hline Links directed to other sites & 0 & 0 & $20 \%$ & $20 \%$ & $60 \%$ \\
\hline $\begin{array}{c}\text { Activities with Moodle ques- } \\
\text { tionnaires }\end{array}$ & 0 & $20 \%$ & 0 & $20 \%$ & $40 \%$ \\
\hline Essay tasks in Moodle & 0 & $20 \%$ & 0 & $20 \%$ & $60 \%$ \\
\hline
\end{tabular}

$\mathrm{SD}=$ Strongly disagree, $\mathrm{DIS}=$ Disagree, $\mathrm{NAND}=$ Neither agree nor disagree; $A G=$ Agree,$S A=$ Strongly agree

\section{CONCLUSION}

As evidenced by the results of this research, in which data regarding the $D L$ experience are favorable, the objectives were achieved, since a DL environment to support the learning process, mediated by the game, has been produced. When evaluation made by public school teachers was examined, it was concluded that deficiencies pointed out by the computer technicians had been solved, and given positive ratings. There was an environmental enrichment in terms of learning support both for tutor and learner. The activities based on a quiz, for example, carry with them evaluation, generating an immediate feedback for the DL user environment. Thus, it can be affirmed that custom-built environments could absorb the elements of formative assessment proposed by Juwah et al. (2004).

Another element that seems relevant to the formulation of future research concerns the vision one has of the entrepreneurship theme in education. It is still seen as an important issue, but remains a barrier and is not included in the educational curriculum, as shown by Lima (2010). Future research can compare teachers using the Bom Bur- guer game supported by a DL environment with others who do not use the game or DL environment, focusing on the students' performance, such as grades obtained by them in other disciplines and the under-graduation carriers they choose. Groups using this DL environment could be compared with others that do not use it, or groups of students that learned entrepreneurship with Bom Burguer or with other experiential learning methods during High School with students that did not. And finally, to validate the results of this research it is necessary to repeat the experiment with a larger group. The inclusion of $D L$ in the game establishes compliance with an important function of the Brazilian educational system, since it allows its use in a non-curricular way, as a complementary activity disengaged from the classroom. Enriched with the DL environment, the game has become even more accessible, as it can be used to educate both tutors (the game features and content, skills and competencies related to entrepreneurship), and students (abilities and skills related to entrepreneurship).

The use of DL has helped to solve some barriers detected previously, and suggests that it can be used as a complement to using business games. With this resource, business games can be improved and become more useful, facilitating the learning process and teacher tasks, such as learning about the game and its functionality, assessment of students, data collection and research. Students are benefited because the environment can be developed to provide multifarious ways of learning and explore the diversity of styles of learning, such as the use of text, video, quiz, activities on line, chats, and forums.

The development of systems to support DL can improve the use of business games, integrating the database of both systems (DL and business game). As shown in Rodrigues (2011), the business game database could be used to provide evidence of learning, including comparing groups. The new tools incorporated into DL systems permit the monitoring and managing of all student activities in the environment. With appropriate models, it is possible to analyze whether students are learning or having difficulties, including what kind of difficulties there are having. Thus, by associating business games and $\mathrm{DL}$, it is possible to manage student learning and provide extra resources to support each student's specific lack of learning. These resources include recent approaches to education, such as the importance of meta-cognition as opposed to the traditional focus on cognition. In this new approach, how to measure and improve meta-cognition has become the main field of research, and DL and games can offer excellent conditions for both collecting and analyzing data. 
Brazilian Journal of Operations \& Production Management

Volume 14, Número 1, 2017, pp. 187-195

DOI: 10.14488/BJOPM.2017.v14.n2.a6

\section{REFERENCES}

Alves, L., Barros, D., Okada, A. (2009), Moodle: Estratégias pedagógicas e estudos de caso. 1 ed. Bahia: EDUNEB.

Bagdonas, E., Patašienè, I., Patašius, M., Skvernys, V. (2010) Use of Simulation and Gaming to Enhance Entrepreneurship. Electronics and Electrical Engineering/ Elektronika Ir Elektrotechnika, Vol. 102, No. 6.

Batista, I. V. C., Cornachione Jr., E. B. (2005) Learning styles influences on satisfaction and perceived learning: analysis of an online business game. Developments in Business Simulation and Experiential Learning, Vol. 32.

Benjacob, M. G. (1998) Distance Learning: An International Perspective. J. Educational Technology Systems, Vol. 26, No. 3, pp. 209-213.

Burch Jr., J.G. (1969) Business Games and Simulation Techniques, Management Accounting, Vol. 51, No. 6, pp. 49-52.

Cole, J., Foster, H. (2008) Using Moodle, 2 ed., O’Reilly Media: Sebastopol/USA.

Conde, M. A., Muñoz, C., García, F. J. (2008). mLearning, the First Step in the Learning Process Revolution. International Journal of Interactive Mobile Technologies (IJIM), Vol. 2, No. 4, pp. 61-63.

Conselho Nacional de Educação/Conselho Pleno - CNE/CP (2002), Resolução CNE/CP 1, 18 de fevereiro de 2002, que institui "As diretrizes Curriculares Nacionais" para a formação de Professores da Educação Básica, em nível superior, curso de licenciatura, de graduação plena.

European Commission (2012), Communication from the commission to the European parliament, the council, the European Economic and Social Committee and the Committee of the Regions. European Commission: Strasbourg, document 669, 20 dez. 2012.

European Union. (2014) Entrepreneurship Education: A Guide for Educators. European Union:Brussels.

Gil, A. C. (2010), Como elaborar projeto de pesquisa. 5 ed. São Paulo: Atlas.

Goldschmidt, P. C. (1977) Simulação e jogo de empresas. Revista de administração de empresas. Rio de Janeiro: FGV.

Goodrich, M. A. (2016). Improving distance education for disabled students: Making the GRADE. Distance Learning, Vol. 13, No. 1, pp. 15-20. Retrieved from http://search.proquest. com/docview/1800737838?accountid=8112.

Griffiths, B., (2016) A faculty's approach to distance learning standardization. Teaching and Learning in Nursing, Vol. 11, No. 4, pp. 157-162 Retrivied from: http://dx.doi.org.ez87. periodicos.capes.gov.br/10.1016/j.teln.2016.04.004

Hafeez, A., Gujjar, A. A., Noreen, Z., (2014) Demanding need of growing technologies in distance learning system.
Turkish Online Journal of Distance Education, Vol. 15, No. 4, pp. 170-180.

Juwah, C., Macfarlane-Dick, D., Matthew, B., Nicol, D., Ross, D., Smith, B., (2004). Enhancing student learning through effective formative feedback. The Higher Education Academy.

Keegan, D. (1996) Definition of distance education. 3 ed. Londres: Routledge Taylor \& Francis,

Kolb A., Kolb D. A. (2009) The Learning Way Meta-cognitive Aspects of Experiential Learning. Simulation \& Gaming, Vol. 40, No. 3, pp. 297-327. Retrivied from http://sag.sagepub.com.ez87.periodicos.capes.gov.br/content/40/3/297. full.pdf+html.

Lima, J. F. (2010) Parecer CNE/CEB № 13/2010 emitido sobre a consulta acerca da inclusão do empreendedorismo como disciplina no currículo do Ensino Fundamental, do Ensino Médio, da Educação Profissional e da Educação Superior. Despacho do Ministro.

Marconi, M.A., Lakatos, E. M. (2008) Técnicas de pesquisa: planejamento e execução de pesquisas, amostragens e técnicas de pesquisa, elaboração, análise e interpretação de dados. São Paulo: Atlas.

McShane, M.Q. (2016) Entrepreneurship and American Education. American Enterprise Institute. May 2016. Retrieved from https://www.aei.org/wp-content/ uploads/2016/05/Entrepreneurship-and-American-education.pdf.

Ministério da Educação do Brasil - MEC (2015). Resolução no. 2 , de 1 o de julho de 2015 , que define as diretrizes curriculares nacionais para a formação inicial em nível superior (cursos de licenciatura, cursos de formação pedagógica para graduados e cursos de segunda licenciatura) e para a formação continuada.

Moran, J. M., Masetto,M. T., Behrens, M. A., Moran, J. M. et al. (2008) Novas tecnologias e mediação pedagógica. Campinas, SP: Papirus.

Pinto, I. M. B. S., Brunstein, J., Martins, A. A. C., Desidério, P. H., Cardoso Sobrinho, C. A., (2016), Systematic review of the literature social entrepreneurship and skills development: an analysis of the past 10 years. International Journal of Innovation (IJI Journal), Vol. 4, No. 1, pp. 33-45. Retrieved from http://www.journaliji.org/index.php/iji/article/ view/67.

Robles, L. Zárraga-Rodríguez, M. (2015), Key Competencies for Entrepreneurship. Procedia Economics and Finance, Vol. 23, pp. 828-832. Retrieved from http://ac.els-cdn.com/S2212567115003895/1-s2.0S2212567115003895-main.pdf?_tid=ab45ba7a-f2b3-11e6896e-00000aacb360\&acdnat $=1487076596$ _bf35e30a2c3b936a1bf8c78d44af9349. 
Rodrigues, J.S. et al. (2011) Brazilian Students and Working Capital: An Analysis of Their Decisions When Using Virtual Market Business Games. International Journal of Engineering Education Vol. 27, No. 3, pp. 644-655.

Rodrigues, J.S. et al. (2012) Empreendedores na escola: educação empreendedora em escolas públicas de Bauru com o jogo Bom Burguer. In: Núcleos de Ensino da Unesp Artigos 2011. Tecnologias da Informação e Comunicação e Material Pedagógico. Organizadores: Sheila Zambello de Pinho, José Brás Barreto de Oliveira, São Paulo: Editora UNESP.

Santos, M. R. G. F., Lovato, S. (2007), Os jogos de empresas como recurso didático na formação de administradores. CINTED, Porto Alegre, RS.

Secretaria da Educação do Estado de São Paulo - SESP (2015). Cadastro de Escolas. Retrieved from: http://www. educacao.sp.gov.br/central-de-atendimento/downloads.asp.

Sezer, B. (2016) Faculty of medicine students' attitudes towards electronic learning and their opinion for an exam- ple of distance learning application. Computers in Human Behavior, Vol. 55, pp.932-939. Retrieved from http://dx.doi. org/10.1016/j.chb.2015.10.018.

Silva, M. S. (2008) Construindo sites com CSS e (X)HTML. São Paulo, SP: Novatec.

Smith, D. (2010) Distance learning: a game application. Developments in Business Simulations and Experiential Learning, Vol. 37, pp-195-201.

U.S. Department of Education (2017), Accreditation and Quality Assurance. Retrieved from https://www2.ed.gov/ about/offices/list/ous/international/usnei/us/edlite-accreditation.html.

Wolfe, J., Flores, L., Ritchie, W. (2002) A business game distance education application: learning outcomes and experiences. Developments in Business Simulation and Experiential Learning, Vol. 29. 